Journal of Southeast Asian

2012

\title{
I am from Laos
}

Danny Kotsombath

dkhotsombath@gmail.com

Follow this and additional works at: https://docs.lib.purdue.edu/jsaaea

\section{Recommended Citation}

Kotsombath, Danny (2012) "I am from Laos," Journal of Southeast Asian American Education and Advancement: Vol. 7 : Iss. 1, Article 13.

DOI: 10.7771/2153-8999.1055

Available at: https://docs.lib.purdue.edu/jsaaea/vol7/iss1/13

This document has been made available through Purdue e-Pubs, a service of the Purdue University Libraries. Please contact epubs@purdue.edu for additional information.

This is an Open Access journal. This means that it uses a funding model that does not charge readers or their institutions for access. Readers may freely read, download, copy, distribute, print, search, or link to the full texts of articles. This journal is covered under the CC BY-NC-ND license. 


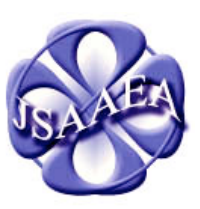

Volume 7 (2012)
Journal of Southeast Asian American Education \& Advancement

WWW.JSAAEA.org
A peer-reviewed scholarly journal published by the National Association for the Education \& Advancement of Cambodian, Laotian, and Vietnamese Americans (NAFEA)

\section{I am from Laos}

\section{by \\ Danny Khotsombath}

I am from water buffaloes, from muddy rice fields and sun-burned backs. I am from the wooden huts, stilted and dusty. I am from a million elephants, ten thousand rice fields, from twelve powerful lords and their slaves.

I am from prehistoric stone jars that once stored rice wine for giants.

I am from more than sixty ethnic groups, from the highlands, midlands, and lowlands. I am from dok champa, the flower from my father's garden, whose sweet scent I savor.

I am from shaved heads and orange robes, from Three Noble Disciplines, Four Noble Truths, and Five Precepts. I am from the Mekong River, lively and strong. I am from sticky rice, papaya salad, beef jerky, from ant egg soup and fermented fish sauce.

I am from the boat festival, rocket festival, and harvest festival.

I am from the alms that I give to each baht, from the belief that what I give I shall receive in return.

I am from the boun, merit-making ceremonies and the baci, whose strings I wear around my wrists.

I am from Laos.

\footnotetext{
@)

SOMIERIIGHISRESEFVED Readers are free to copy, display, and distribute this article, as long as the work is attributed to the author(s) and the Journal of Southeast Asian American Education \& Advancement, it is distributed for noncommercial purposes only, and no alteration or transformation is made in the work. More details of this Creative Commons license are available at http://creativecommons.org/licenses/by-nc-nd/3.0/. All other uses must be approved by the author(s) or JSAAEA.
} 


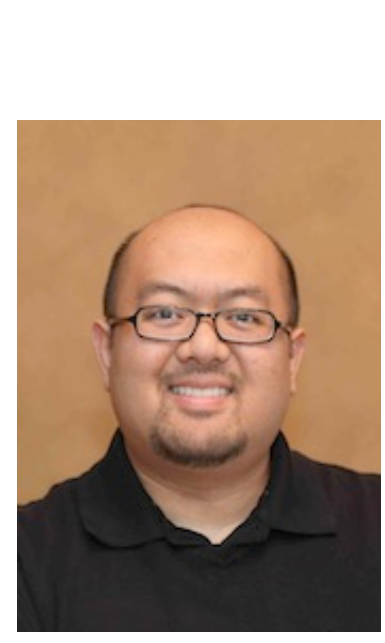

\begin{abstract}
About the Author
Born and raised in Minneapolis, Minnesota to Lao immigrant parents, Danny Khotsombath is currently pursuing a graduate degree in Educational Policy Studies with a focus on Diversity and Equity through the University of Illinois at Urbana-Champaign. His work as an academic adviser at the University of Minnesota supports the achievement of students of color, especially those from underrepresented populations. Having experienced educational barriers as a student of color, his interests include diversity and equity issues, critical pedagogy, and culturally responsive instruction.
\end{abstract}




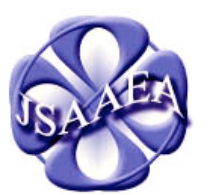

Volume 7 (2012)

\section{Journal of Southeast Asian American Education \& Advancement}

\author{
WWW.JSAAEA.org
}

\section{Editor}

Dr. Wayne E. Wright

University of Texas, San Antonio

\author{
Associate Editors \\ Dr. Chhany Sak-Humphry \\ University of Hawaii at Manoa
}

Dr. Phitsamay Sychitkokhong Uy

University of Massachusetts, Lowell

\section{Book Review Editor}

Dr. Vichet Chhuon

University of Minnesota

\section{Creative Works Editor \\ Bryan Thao Worra \\ Lao Assistance Center}

Special Advisor

Gregory Green

Curator, Echols Collection on Southeast Asia, Cornell University Library

Journal Manager

Sovicheth Boun

University of Texas, San Antonio
A peer-reviewed

scholarly journal published by the

National Association

for the Education \&

Advancement of

Cambodian, Laotian,

and Vietnamese

Americans (NAFEA)

Comments and questions for the editorial staff may be directed to jsaaea@1ists.sis.utsa.edu

\section{Editorial Review Board}

\author{
Dr. Steve Arounsack \\ California State University, Stanislaus \\ Dr. Phala Chea \\ Lowell Public Schools \\ Dr. Loan Dao \\ Cancer Prevention Institute of California \\ Dr. Changming Duan \\ University of Missouri, Kansas City \\ Dr. Jeremy Hein \\ University of Wisconsin - Eau Claire \\ Dr. Samlong Inthaly \\ Minneapolis Public Schools \\ Dr. Kevin K. Kumashiro \\ University of Illinois, Chicago
}

Dr. Carl L. Bankston III

Tulane University

Dr. George Chigas

University of Massachusetts, Lowell

Dr. Hien Duc Do

San Jose State University

Dr. Sophal Ear

U.S. Naval Postgraduate School

Dr. Nancy H. Hornberger

University of Pennsylvania

Dr. Peter Nien-Chu Kiang

University of Massachusetts, Boston

Dr. Ha Lam

Arizona State University 

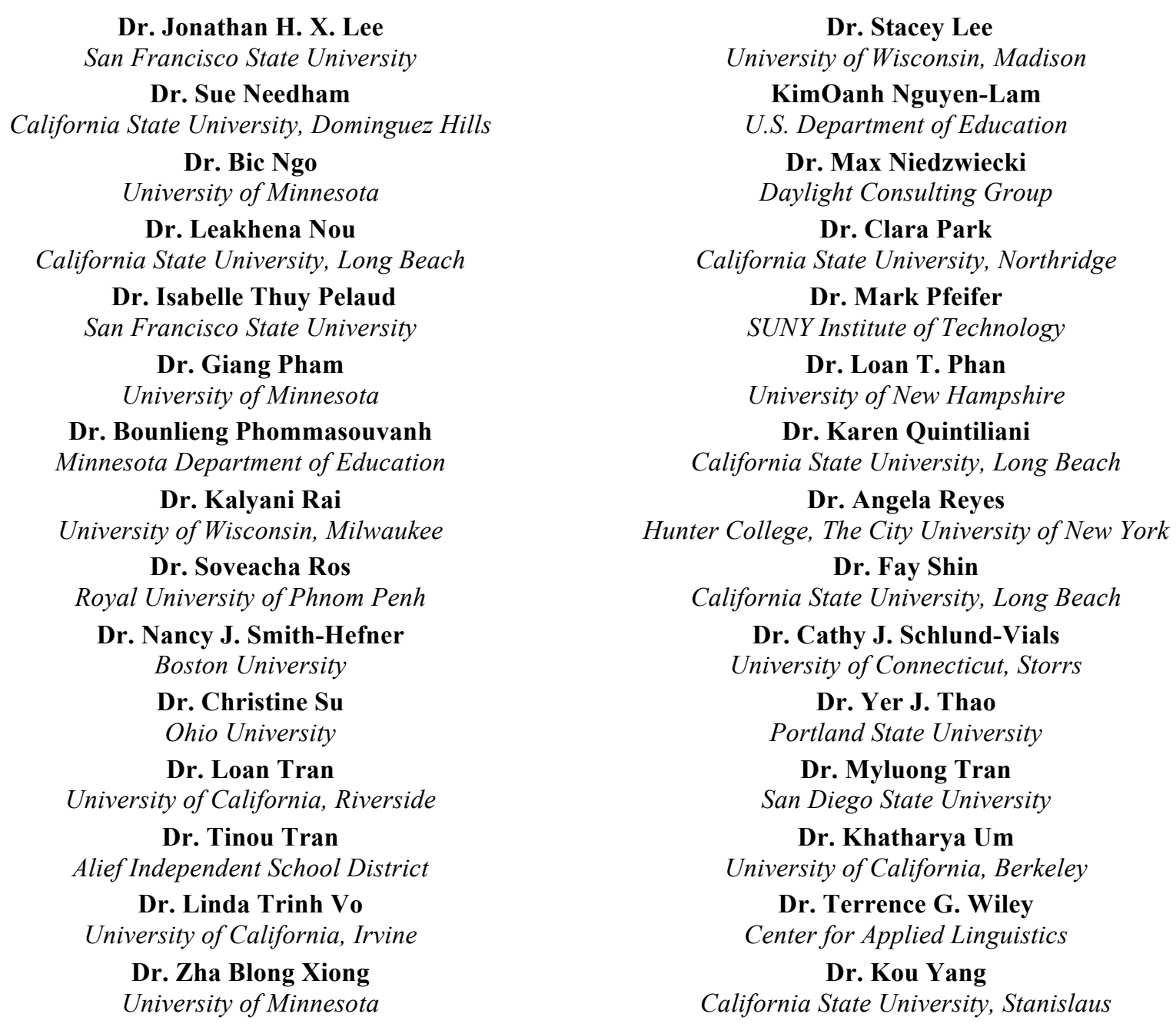

\section{Doctoral Student Editorial Review Board}

\author{
Keo Chea-Young \\ University of Pennsylvania \\ Ketmani Kouanchao \\ California State University, Fullerton \\ Ravy Lao \\ University of California, Santa Barbara \\ Thien-Huong Ninh \\ University of Southern California \\ Vanna Som \\ Harvard University \\ Krissyvan Truong \\ Claremount Graduate University \\ Yang Sao Xiong \\ University of California, Los Angeles
}

\author{
Annie BichLoan Duong \\ San Joaquin County Office of Education \\ Peter Tan Keo \\ Columbia University \\ Monirith Ly \\ Texas State University-San Marcos \\ Malaphone Phommasa \\ University of California, Santa Barbara \\ Alisia Tran \\ University of Minnesota \\ Silvy Un \\ University of Minnesota \\ Yeng Yang \\ University of Texas, San Antonio
}

